\title{
Proposed Plan for Final Remedial Action for the Groundwater Operable Unit at the Chemical Plant Area of the Weldon Spring Site, Weldon Spring, Missouri
}

August 2003

prepared by

Environmental Assessment Division, Argonne National Laboratory

prepared for

U.S. Department of Energy, Weldon Spring Site Remedial Action Project,

Weldon Spring, Missouri, under Contract W-31-109-ENG-38 



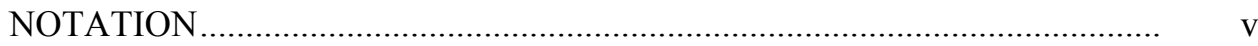

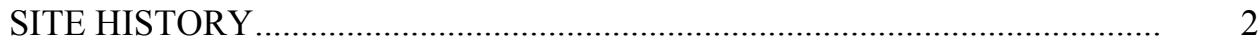

CURRENT GROUNDWATER AND SPRING WATER CONDITIONS ........ 2

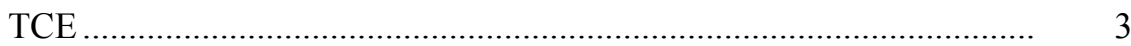

Nitrate............................................................................ 4

Uranium ........................................................................ 4

Nitroaromatic Compounds ......................................................... 4

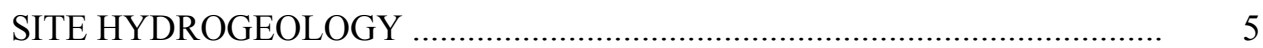

CURRENT GROUNDWATER USE ....................................................... 6

SCOPE AND ROLE OF THE PROPOSED PREFERRED ALTERNATIVE... $\quad 7$

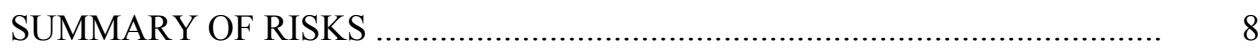

REMEDIAL ACTION OBJECTIVES ................................................. 9

SUMMARY OF REMEDIAL ALTERNATIVES ....................................... 10

Alternative 1: No Further Action ................................................ 10

Alternative 2: Long-Term Monitoring with Institutional Controls ...... 10

Alternative 3: Monitored Natural Attenuation with

Institutional Controls ........................................... 11

EVALUATION OF ALTERNATIVES ....................................................... 11

PREFERRED ALTERNATIVE ......................................................... 13

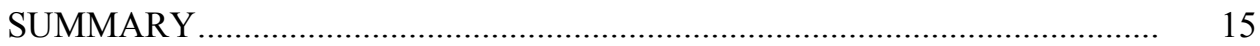

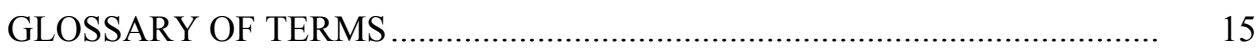

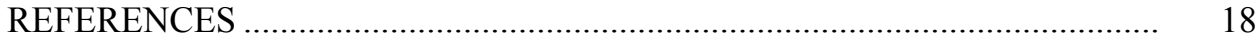

APPENDIX A: CONTAMINATION CONTOURS ............................. A 


\section{FIGURES}

$1 \quad$ Location of the Weldon Spring Chemical Plant Area ........................... 1

2 Locations of Monitoring Wells at the Chemical Plant Area .................. 3

3 Springs and Drainage Areas in the Chemical Plant Area....................... 6

$4 \quad$ Institutional Controls Location Map for the Chemical Plant Area......... 14

A.1 TCE Contamination Contour Based on Average Concentrations for 2002 at the Chemical Plant Area .................................................... A-3

A.2 Nitrate Contamination Contour Based on Average Concentrations for 2002 at the Chemical Plant Area .................................................... A-4

A.3 Uranium Contamination Contour Based on Average Concentrations for 2002 at the Chemical Plant Area .................................................... A-5

A.4 2,4-DNT Contamination Contour Based on Average Concentrations for 2002 at the Chemical Plant Area ................................................... A-6

A.5 2,6-DNT Contamination Contour Based on Average Concentrations for 2002 at the Chemical Plant Area ..................................................... A-7

A.6 2,4,6-TNT Contamination Contour Based on Average Concentrations for 2002 at the Chemical Plant Area ................................................. A-8 


\section{NOTATION}

The following is a list of the acronyms, initialisms, and abbreviations (including units of measure) used in this document.

\section{ACRONYMS, INITIALISMS, AND ABBREVIATIONS}

\section{General}

$\begin{array}{ll}\text { ARAR } & \text { applicable or relevant and appropriate requirement } \\ \text { BRA } & \text { baseline risk assessment } \\ \text { CERCLA } & \text { Comprehensive Environmental Response, Compensation, and Liability Act } \\ \text { COC } & \text { contaminant of concern } \\ \text { DA } & \text { U.S. Department of the Army } \\ \text { DHSS } & \text { Missouri Department of Health and Senior Services } \\ \text { DOE } & \text { U.S. Department of Energy } \\ \text { EPA } & \text { U.S. Environmental Protection Agency } \\ \text { FS } & \text { feasibility study } \\ \text { GWOU } & \text { groundwater operable unit } \\ \text { IC } & \text { institutional control } \\ \text { ICO } & \text { in-situ chemical oxidation } \\ \text { IROD } & \text { Interim Record of Decision } \\ \text { LTS\&MP } & \text { Long-Term Surveillance and Maintenance Plan } \\ \text { MCL } & \text { maximum contaminant level } \\ \text { MDC } & \text { Missouri Department of Conservation } \\ \text { MDNR } & \text { Missouri Department of Natural Resources } \\ \text { MDOH } & \text { Missouri Department of Health } \\ \text { MoDOT } & \text { Missouri Department of Transportation } \\ \text { MNA } & \text { monitored natural attenuation } \\ \text { MOA } & \text { Memorandum of Agreement } \\ \text { NEPA } & \text { National Environmental Policy Act } \\ \text { O\&M } & \text { operations and maintenance } \\ \text { PP } & \text { Proposed Plan } \\ \text { RA } & \text { remedial action } \\ \text { RAO } & \text { remedial action objective } \\ \text { RBC } & \text { risk-based concentration } \\ \text { RD } & \text { remedial design } \\ \text { RI } & \text { remedial investigation } \\ \text { ROD } & \text { Record of Decision } \\ & \end{array}$




\section{Chemicals}

$\begin{array}{ll}\text { 1,3-DNB } & \text { 1,3-dinitrobenzene } \\ \text { DNT } & \text { dinitrotoluene } \\ \text { 2,4-DNT } & \text { 2,4-dinitrotoluene } \\ \text { 2,6-DNT } & \text { 2,6-dinitrotoluene } \\ \text { NB } & \text { nitrobenzene } \\ \text { TCE } & \text { trichloroethylene } \\ \text { TNT } & \text { trinitrotoluene } \\ 1,3,5-\mathrm{TNB} & 1,3,5 \text {-trinitrotoluene } \\ \text { 2,4,6-TNT } & 2,4,6 \text {-trinitrotoluene }\end{array}$

Units of Measure

$\begin{array}{ll}\mathrm{d} & \text { day(s) } \\ \mathrm{ft} & \text { foot (feet) } \\ \mathrm{gal} & \text { gallon } \\ \mathrm{ha} & \text { hectare(s) } \\ \mathrm{km} & \text { kilometer(s) } \\ \mathrm{L} & \text { liter(s) } \\ \mathrm{m} & \text { meter(s) } \\ \mathrm{mg} & \text { milligram(s) } \\ \mathrm{mi} & \text { mile(s) } \\ \mathrm{min} & \text { minute(s) } \\ \mathrm{pCi} & \text { picocurie(s) } \\ \mu \mathrm{g} & \text { microgram(s) }\end{array}$




\section{THE U.S. DEPARTMENT OF ENERGY (DOE) IS ISSUING A PROPOSED PLAN FOR PUBLIC COMMENT ....}

This Proposed Plan (PP) presents the preferred alternative for addressing contaminated groundwater and springs at the Chemical Plant area of the Weldon Spring site, in Weldon Spring, Missouri. The site is located about $30 \mathrm{mi}$ west of St. Louis, in St. Charles County (Figure 1). This proposed action constitutes the final remedial action for the Weldon Spring site. The residual contamination in groundwater and springs at the Chemical Plant area is the only remaining contamination that needs to be addressed for the site. All other contamination has been addressed by previous remedial actions. After this remedial action is implemented, long-term surveillance and maintenance activities will maintain the effectiveness of all remedial actions conducted at the Weldon Spring site, including this final remedial action for groundwater and springs that is being proposed in this plan.

DOE complies with the requirements of the Comprehensive Environmental Response, Compensation, and Liability Act (CERCLA) in conducting remedial activities at the site. National Environmental Policy Act (NEPA) values have been incorporated into the CERCLA process; that is, the analysis conducted and presented in the remedial investigation/feasibility study (RI/FS) reports included an evaluation of environmental impacts that is comparable to that performed under NEPA.

This PP is required under CERCLA to (1) notify the public and present a brief analysis of the remedial action alternatives, (2) identify and present the rationale for the preferred remedial action alternative identified in the PP, (3) summarize key information from the RI/FS evaluations, including the Baseline Risk Assessment (BRA), and (4) inform the public of its role in the remedy selection process and give the public the opportunity to participate in the process.

Remediation activities at the Weldon Spring site have been coordinated with the U.S. Environmental Protection Agency (EPA) and the Missouri Department of Natural Resources (MDNR). The EPA has overall oversight and approval authority, with consultation provided by the MDNR.

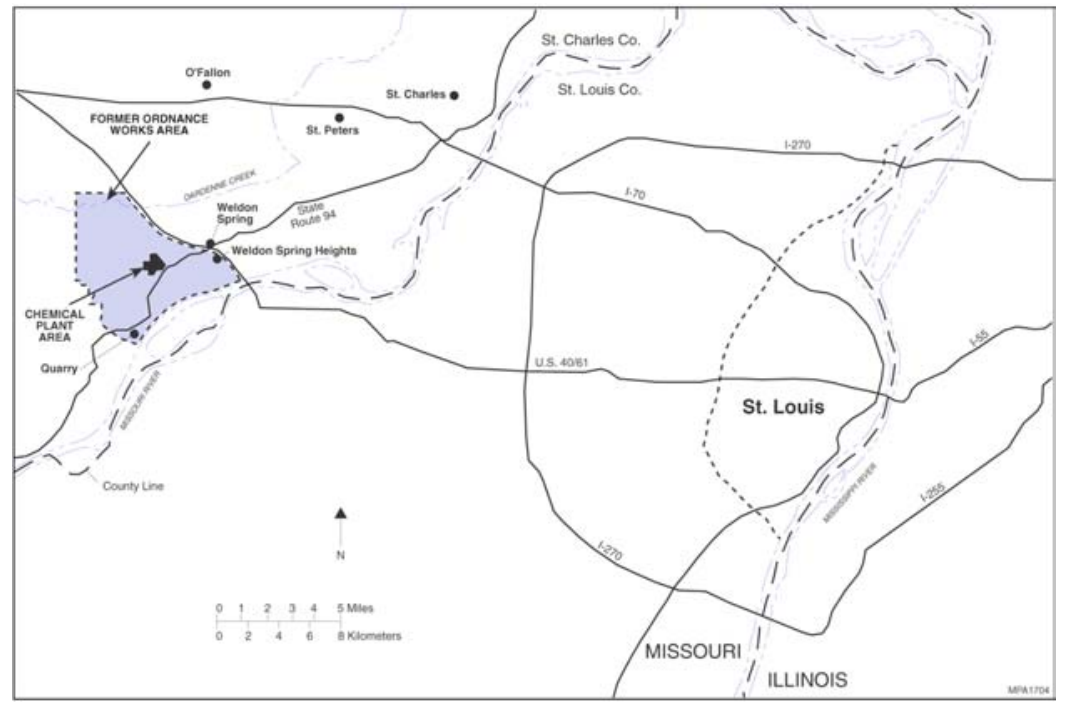

Figure 1 Location of the Weldon Spring Chemical Plant Area
A range of alternatives was considered in identifying the preferred alternative. The alternatives were developed after careful analysis of geological, environmental, and human health and ecological risk data and an evaluation of the effectiveness, implementability, and cost of the various technologies available for groundwater remediation at the Chemical Plant area. Monitored natural attenuation (MNA) coupled with institutional controls (ICs) and contingency activities has been selected as the preferred alternative. 
DOE encourages public review and comment on this proposed remedial action plan for groundwater and springs at the Chemical Plant area. Comments on all of the evaluated alternatives and the proposed remedial action will be received during the public review period from August 4 through September 3, 2003. Oral and written comments will be received at a public meeting to be held on August 13, 2003, at the Interpretive Center located at the site. Written comments may either be submitted at the public meeting or mailed by September 3, 2003, to:

\author{
Pamela Thompson, Site Manager \\ U.S. Department of Energy \\ Weldon Spring Site Remedial \\ Action Project \\ 7295 Highway 94 South \\ St. Charles, MO 63304
}

Additional details about the site and the remedial action alternatives may be found in the $\mathrm{RI} / \mathrm{FS}$ reports that have been prepared to address groundwater and springs at the Chemical Plant area - these are the RI (U.S. Department of Energy [DOE] and U.S. Department of the Army [DA] 1997b [DOE/OR/21548-571]), BRA (DOE and DA 1997a [DOE/OR/21548-568]), FS (DOE and DA 1998 [DOE/OR/21548-569]), Supplemental FS (DOE 1999 [DOE/OR/21548-783]), Interim Record of Decision (IROD; DOE 2000 [DOE/OR/21548-798]), Supporting Evaluation Report (DOE 2003b [DOE/GJ/79491-934]) — and in other supporting technical reports. These documents can be found in the Administrative Record file located at the site and also through the Web at www.gjo.doe.gov/ programs/ltsm.

Responses to timely comments will be provided in the responsiveness summary that will be made available with the Record of Decision (ROD). The ROD will explain how the comments were considered and incorporated into the decisions presented in the ROD.

\section{SITE HISTORY}

The Weldon Spring Chemical Plant property covers about 88 ha (217 acres) and lies within the boundary of the former Weldon Spring Ordnance Works, which is about 6,974 ha (17,232 acres). Both sites are on the EPA's National Priority List. The remediation of the former Weldon Spring Ordnance Works site is being conducted by the U.S. Army. Groundwater contamination at the Ordnance Works primarily involves nitroaromatic compounds.

The Chemical Plant property was used for trinitrotoluene (TNT) and dinitrotoluene (DNT) production from 1941 to 1945 and later as a uranium processing facility from 1957 to 1966. The sources of groundwater contamination have been remediated, which included 44 buildings and structures, four Raffinate Pits (radioactive and chemical waste retention ponds), two ponds (Ash Pond and Frog Pond), and two former dumps (north and south). Various groundwater investigations have also been conducted to evaluate the extent of contamination and to determine how best to remediate this contamination. These investigations included the following: (1) groundwater monitoring since 1987 (including a comprehensive RI done in 1995); (2) dye-trace studies conducted in 1995 and 1998; (3) pump testing in 1998; (4) field studies conducted in 2001 to evaluate enhanced groundwater removal technologies; and (5) in situ chemical oxidation for trichloroethylene (TCE) treatment conducted in 2002. The results of these investigations have been incorporated into the discussions presented below.

\section{CURRENT GROUNDWATER AND SPRING WATER CONDITIONS}

The current monitoring program consists of 86 wells (including 5 wells that monitor the 
performance of the Chemical Plant disposal cell) and 5 springs. Approximately 60 additional monitoring wells have also been constructed and sampled since 1987 but have been abandoned. The current network of wells monitored at the Chemical Plant area is shown in Figure 2. The contaminants of concern (COCs) in groundwater are TCE, nitrate, uranium, and nitroaromatic compounds. The nitroaromatic compounds of concern include 2,4-DNT, 2,6-DNT, 2,4,6-TNT, 1,3,5-trinitrobenzene $\quad(1,3,5$-TNB $), \quad 1,3$-dinitrobenzene (1,3-DNB), and nitrobenzene (NB). Presentations of contaminant distributions in Appendix A depict the locations where contaminants in groundwater exceed appropriate

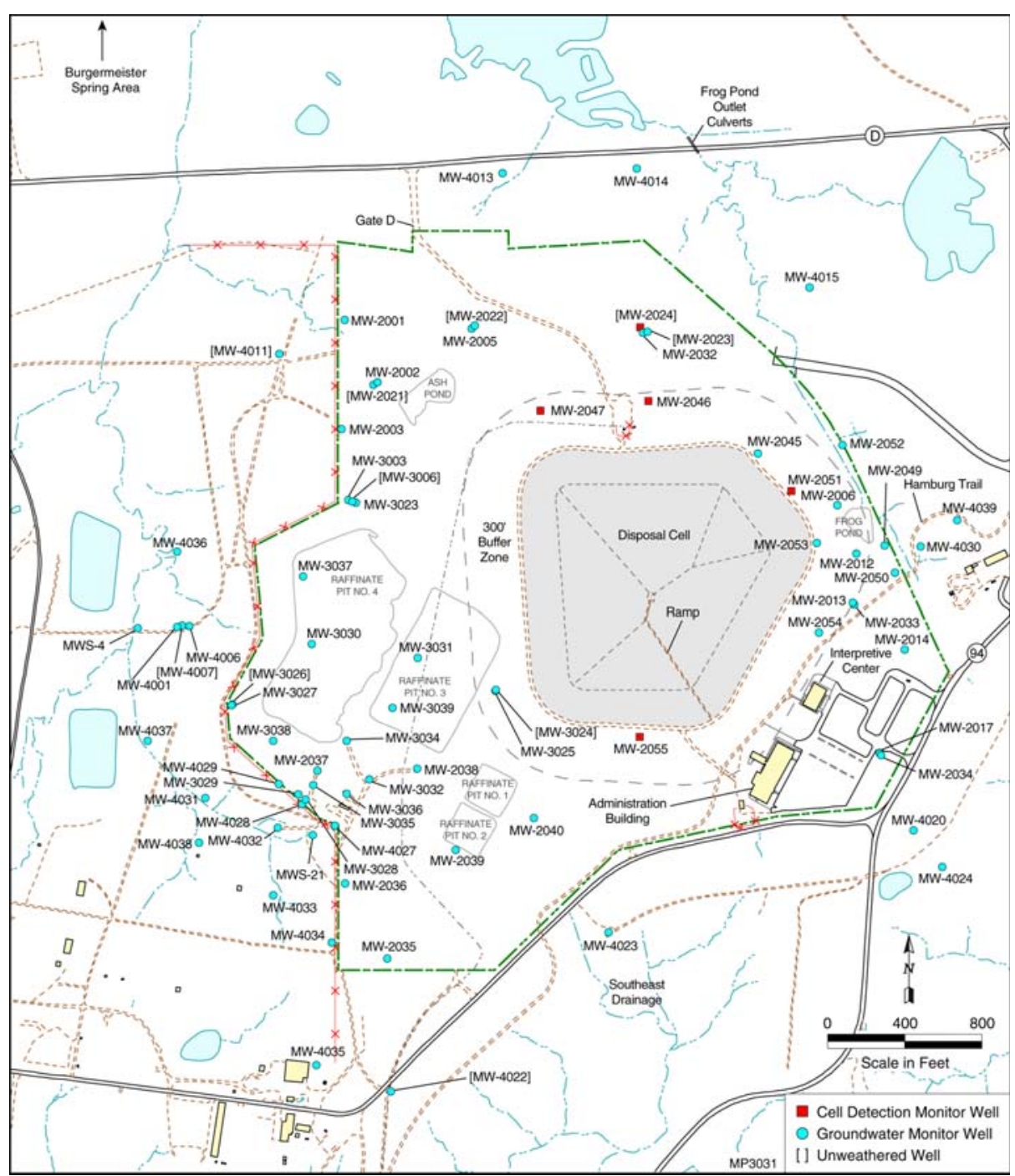

Figure 2 Locations of Monitoring Wells at the Chemical Plant Area federal or state drinking water or water quality standards or risk-based levels (when no standards are available).

\section{TCE}

TCE contamination exceeding the maximum contaminant level (MCL), which is $5 \mu \mathrm{g} / \mathrm{L}$, is primarily within the Chemical Plant boundary (in the vicinity of the former Raffinate Pits) extending just beyond the DOE boundary onto the adjacent Army site. Contamination is primarily limited to the weathered portion of the shallow aquifer. The source of TCE contamination was drums discarded in Raffinate Pit 4. Decreasing trends since 1996 have been observed, with the maximum concentration reported at $1,100 \mu \mathrm{g} / \mathrm{L}$; data collected in 2002 indicated there was a maximum concentration of $580 \mu \mathrm{g} / \mathrm{L}$, which was reported for MW-4029 (a monitoring well located in the Chemical Plant boundary near the Raffinate Pits). Low concentrations of TCE (about $1 \mu \mathrm{g} / \mathrm{L}$ ) have been detected in only one spring, SP 6303.

During 2001, the pilot-phase in situ chemical oxidation (ICO) process was performed as specified in the IROD (DOE 2000). The pilot-phase ICO appears to have 
achieved temporary reduction of TCE within the area of influence (approximately $100 \mathrm{ft}$ from the injection point). Dispersion of the oxidant favored a downgradient direction toward a preferential flow feature (paleochannel), and uniform distribution was not achieved. The latest data collected in 2003 at some locations where TCE was treated and reduced to nondetectable levels have indicated levels to be back to pretreatment concentrations. This possibility was expected and is most likely due to recontamination from TCE that is present in other nearby portions of the groundwater that were not reduced by the pilotphase ICO. The original source of TCE contamination, which was drums discarded in Raffinate Pit 4, has been removed as part of the remedial action for the Chemical Plant Operable Unit.

\section{Nitrate}

The highest concentrations of nitrate have been measured in the vicinity of the Raffinate Pits and Ash Pond, which are historical sources of this contaminant. Nitrates are mobile in the shallow aquifer system. Data for 2002 show a range of 0.4 to $826 \mathrm{mg} / \mathrm{L}$, with the maximum reported for MW-4029. Nitrate concentrations that exceed the MCL, which is $10 \mathrm{mg} / \mathrm{L}$, are observed at locations within the DOE Chemical Plant boundary, at locations on Missouri Department of Conservation (MDC) property and at locations within the adjacent DA site. Remediation activities in the Raffinate Pits area and Ash Pond in 1998 have resulted in slight increases in contaminant concentrations in several of the nearby wells. This effect is expected as a result of large-scale soil excavation and is anticipated to be temporary. The majority of the wells exhibit stationary trends, with a few beginning to show downward trends.

Nitrate concentrations at Burgermeister Spring vary with changes in flow rate but are generally lower than concentrations measured in groundwater. Lower concentrations occur during high flow rates because of dilution. Nitrate data for 2002 indicate a range of 0.94 to $11 \mathrm{mg} / \mathrm{L}$.

\section{Uranium}

Uranium concentrations exceeding the MCL are located within the Chemical Plant boundary and at several springs located on MDC property. The Raffinate Pits were the historical source of uranium in groundwater as it entered the aquifer via infiltration through the overburden. Contamination is primarily limited to the weathered portion of the shallow aquifer. Adsorption of uranium onto the overburden limited its extent in groundwater. Data collected for uranium in 2002 ranged from 0.1 to $60 \mathrm{pCi} / \mathrm{L}$, and concentrations in only two wells exceeded the recently promulgated $\mathrm{MCL}$ of $30 \mu \mathrm{g} / \mathrm{L}$ (or $20 \mathrm{pCi} / \mathrm{L}$, based on the isotopic ratio determined for the Weldon Spring site). These wells are MW-3024 (at $60 \mathrm{pCi} / \mathrm{L}$ ) and MW-3030 (at $57 \mathrm{pCi} / \mathrm{L}$ ). Both locations are within the Chemical Plant boundary. Because of the relatively low concentrations, downward trends are not expected to be clearly established until several more years of groundwater data are collected following remediation of the Raffinate Pits.

Uranium has been detected at Burgermeister Spring and at the Southeast Drainage (SP-5304). In 2002, uranium ranged from 8.6 to $100 \mathrm{pCi} / \mathrm{L}$ and from 9.4 to $103 \mathrm{pCi} / \mathrm{L}$, respectively, at these springs. Uranium concentrations measured at Burgermeister Spring are generally greater than those measured in groundwater at the Chemical Plant. Base flow concentrations have shown a downward trend at Burgermeister Spring since 1999 and a stationary trend in high flow conditions.

\section{Nitroaromatic Compounds}

Nitroaromatic compounds occur in groundwater in the northeastern and southwestern 
portions of the site where TNT production lines were located both on the Chemical Plant site and the adjacent DA site. Contamination occurs predominantly in the weathered portion of the shallow aquifer. In 2002, maximum concentrations of $1,600 \mu \mathrm{g} / \mathrm{L}$ for $2,4-\mathrm{DNT}, \quad 1,300 \mu \mathrm{g} / \mathrm{L}$ for 2,6-DNT, $280 \mu \mathrm{g} / \mathrm{L}$ for 1,3,5-TNB, $290 \mu \mathrm{g} / \mathrm{L}$ for 2,4,6-TNT, $1.7 \mu \mathrm{g} / \mathrm{L}$ for $1,3-\mathrm{DNB}$, and $69 \mu \mathrm{g} / \mathrm{L}$ for NB were detected. These maximums have been reported for one particular well, MW-2012. Increasing trends were observed, starting in 1999, from this monitoring well near the Frog Pond area located within the Chemical Plant boundary and are most likely due to excavation of TNT-impacted soil in this area or excavation of the nearby waste lagoon conducted for the adjacent Weldon Spring Ordnance Works site by the DA. The increase in concentrations is expected to be temporary, as the sources of nitroaromatic contamination have been removed and water quality should improve over time. Nitroaromatic compound impact at the remainder of the site is significantly less. Of the nitroaromatic compounds sampled for at Burgermeister Spring in 2002, only 2,6-DNT was detected with an average of $0.12 \mu \mathrm{g} / \mathrm{L}$. At the Southeast Drainage, 1,3,5-TNB, 2,4,6-TNT, and 2,6-DNT were detected with average concentrations of $0.21 \mu \mathrm{g} / \mathrm{L}, 26 \mu \mathrm{g} / \mathrm{L}$, and $0.12 \mu \mathrm{g} / \mathrm{L}$, respectively.

\section{SITE HYDROGEOLOGY}

Two major geologic units are present beneath the Chemical Plant area: unconsolidated surface materials and underlying limestone bedrock. Unconsolidated surface materials as much as $18 \mathrm{~m} \mathrm{(60} \mathrm{ft)} \mathrm{thick} \mathrm{are} \mathrm{clay-rich} \mathrm{and} \mathrm{mostly}$ of glacial origin. The uppermost bedrock unit in the area, the Burlington-Keokuk Limestone, has been separated into two zones with different physical characteristics: weathered zone underlain by an unweathered zone. The weathered unit ranges in thickness from 3 to $17 \mathrm{~m}$ (10 to $55 \mathrm{ft})$ and consists of highly fractured limestone with solution voids and enlarged fractures. Fracturing in the bedrock is predominantly horizontal. Solution features are common in the weathered portion of the Burlington-Keokuk Limestone and range from pinpoint vugs to small zones of core loss, typically less than $1.5 \mathrm{~m}$ (5 ft) (DOE 1992); however, these features are generally clay filled. The unweathered unit has less fracturing and weathering than the weathered unit.

Three regional aquifers are present in the vicinity of the Chemical Plant area: a shallow unconfined aquifer (although it may be locally confined), a middle confined aquifer, and a deep confined aquifer. As indicated by characterization data, the shallow unconfined aquifer has been affected by former activities at the Chemical Plant area; therefore, it is the groundwater system of primary interest for this PP. The aquifer consists of the Burlington-Keokuk Limestone, the Fern Glen Formation (both limestone units), and the overburden to the north of the Chemical Plant.

An east-west-trending groundwater divide results in two distinct drainage systems in the Chemical Plant area. This divide presently is located along the southern boundary of the Chemical Plant property. Previously, the divide was situated beneath the Raffinate Pit area because of extensive recharge from the pits, which have since been removed. At the Chemical Plant area, shallow groundwater north of the divide flows to the north and into a karst conduit system that discharges at Burgermeister Spring (Figure 3). Transport through this conduit can be very rapid, as demonstrated by subsurface dye-trace studies performed at the Chemical Plant site in 1995 and 1998 (DOE and DA 1997b). Water discharged at Burgermeister Spring then mixes with other surface water and with ponded water in Lake 34. Any dissolved contaminants in the discharged groundwater are then subject to extensive dilution and, for some, physical and chemical degradation. Because most of the shallow groundwater beneath the Chemical Plant area discharges to the surface in the vicinity of Burgermeister Spring, the spring defines the northernmost extent of direct 


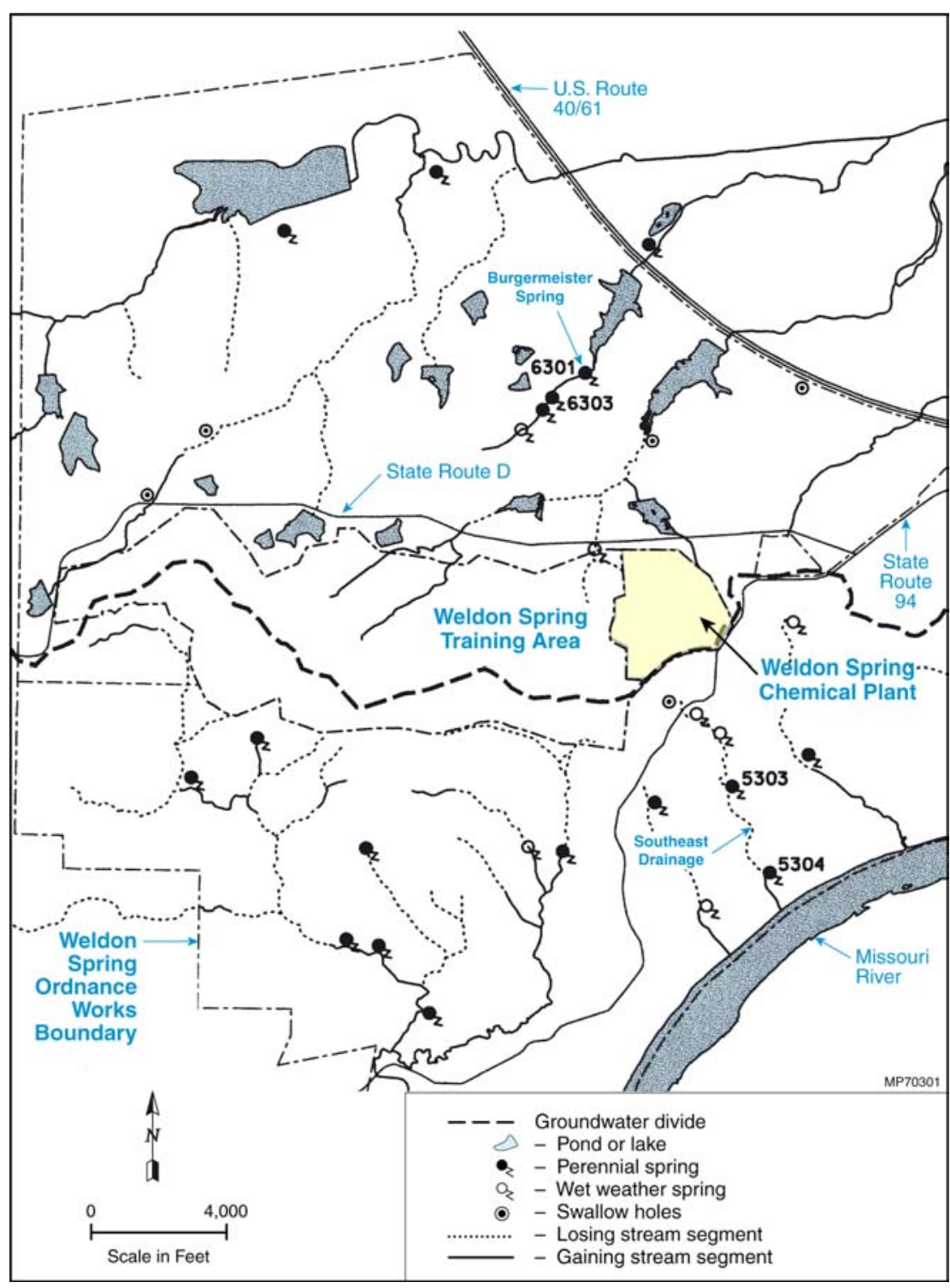

Figure 3 Springs and Drainage Areas in the Chemical Plant Area downgradient springs. Historically, contaminated groundwater from Raffinate Pits 1 and 2 flowed into the Southeast Drainage. This drainage was used as a discharge point for effluent from the Chemical Plant operations, and because this drainage has losing stream segments in its upper reaches, mixing between groundwater and surface water occurred. Springs in the Southeast Drainage act as end points for impacted groundwater in this drainage and provide ideal locations for monitoring.

The shallow groundwater system beneath the Chemical Plant area is hydrogeologically complex and is characterized by fractures, conduits, paleochannels, and dissolution or weathering features. Because of these features, the aquifer exhibits highly heterogeneous and anisotropic values in hydraulic conductivity and transmissivity from place to place. Pump tests performed in July 1998 and the field test performed in 2001 to groundwater transport from the site and provides an ideal location for monitoring end point contaminant concentrations.

Groundwater south of the divide at the Chemical Plant area flows south to southeast toward the Missouri River, primarily through the Southeast Drainage. Presently, this represents only a small portion of the Chemical Plant, and no groundwater contamination attributable to the Chemical Plant site is present south of the divide; therefore, there is not presently a groundwater component to the contamination present in the determine the effects of groundwater withdrawal and injection on the aquifer further demonstrated the variability of the aquifer and the low unsustainable yields of groundwater (MK-Ferguson and Jacobs Engineering Group 1998).

\section{CURRENT GROUNDWATER USE}

As a whole, the shallow bedrock aquifer beneath the boundary of the Chemical Plant property and the adjacent DA and MDC properties 
is currently not used for drinking water or for irrigation.

No active private wells are located within $1 \mathrm{mi}$ of the Chemical Plant. One well, which is used for irrigation at the Missouri Research Park, is located within $2 \mathrm{mi}$, but is cross gradient of the site and therefore does not have the potential for impact. No domestic wells are known to be active within the Chemical Plant area, the adjacent Ordnance Works area, or in the Busch Conservation area (Vogel 2003). The privately owned domestic water wells that are closest to the site are located $2.1 \mathrm{mi}$ to the north-northeast. These wells are estimated to be 70 to $91 \mathrm{~m} \mathrm{(325} \mathrm{to} 350 \mathrm{ft}$ ) below the ground surface. Although these wells produce water that includes groundwater from the shallow aquifer, the potential for impact from contaminated groundwater originating from the Chemical Plant site is low. Groundwater field studies have supported that the preferential flow direction for groundwater from the site is to the northwest toward Burgermeister Spring and the 6300 Drainage (DOE and DA 1997b). If active wells were present between the site and this drainage, the likelihood for impact would be high.

The Missouri Department of Health $(\mathrm{MDOH})$, now Missouri Department of Health and Senior Services (DHSS), initiated a sampling program for private drinking water wells surrounding the Weldon Spring site in 1982. The number of wells was expanded over time in an effort to fully investigate the area around the Chemical Plant and the former Army Ordnance Works area. When a well is no longer used for consumption, it is removed from the sampling program. In 2003, the DHSS will sample several wells within approximately $6 \mathrm{mi}$ of the Chemical Plant area. Historically, wells closer to the site were sampled quarterly, and those in outlying areas were sampled annually. Presently, wells are sampled on a semiannual or annual basis. Sampling results indicate background levels of those parameters analyzed, including radiological parameters (Basko 2003). The only historically impacted wells identified were at Twin Island Lakes (Dardenne Lakes) located northeast of the Chemical Plant and Ordnance Works area, where elevated nitroaromatic compounds were detected. This impact is not due to the DOE Weldon Spring site and has since been investigated and addressed by the DA as part of its Ordnance Works CERCLA site.

\section{SCOPE AND ROLE OF THE PROPOSED PREFERRED ALTERNATIVE}

This preferred alternative for groundwater and springs at the Chemical Plant area constitutes the final component of the phased cleanup process implemented at the Weldon Spring site. The groundwater operable unit (GWOU) that is the subject of this PP constitutes the fourth operable unit in the overall cleanup strategy established for the Weldon Spring site. The first three operable units were as follows: (1) the Quarry Bulk Waste Operable Unit, which addressed contaminated bulk waste at the quarry; (2) the Chemical Plant Operable Unit, which addressed contaminated soil and structures located at the Chemical Plant, including the construction of the on-site disposal cell; and (3) the Quarry Residuals Operable Unit, which addressed the remaining or residual contamination at the quarry area, including contaminated groundwater.

The RI/FS documents that included a PP developed for the GWOU were released to the public in 1999. That PP identified a proposed action of active remediation of the TCE and longterm monitoring for the other COCs. On the basis of comments received from the MDNR and members of the public expressing concern that the proposal included active treatment for only TCE and not for all COCs, DOE decided to (1) postpone the final groundwater decision until further field studies could be conducted to reexamine the effectiveness and practicality of further active remediation of the other COCs and (2) move forward with the treatment of TCE. Consequently, 
an IROD was signed in September of 2000. The IROD specified in place treatment (via ICO) of the TCE in groundwater at the Chemical Plant area. The scope of work identified in the IROD was conducted and completed in 2002, although the MCL of $5 \mu \mathrm{g} / \mathrm{L}$ was not sustained throughout the plume. The additional field studies were conducted and completed in 2001. The results from these two activities have been incorporated into selecting the preferred alternative presented in this plan.

This PP will be followed by a ROD and a remedial design/remedial action (RD/RA) work plan. The upcoming ROD for the GWOU will be the last ROD needed to complete CERCLA remedial actions for the Weldon Spring site. This final GWOU ROD will reflect the change to the remedy stipulated in the IROD for TCE; that is, the remedy that would be stipulated in the ROD will serve as the final remedy for all COCs for the GWOU, including the TCE that remains after the implementation of the IROD. Finally, the site Long-Term Surveillance and Maintenance Plan (DOE 2003a) will incorporate long-term monitoring activities stipulated in the GWOU final ROD and the RD/RA work plan.

\section{SUMMARY OF RISKS}

As part of the RI/FS, standard EPA methods were used to evaluate potential risks to human health and the environment from groundwater and spring water contamination. The conclusion is that site contamination levels are acceptable for the recreational visitor but not for the resident.

Risk scenarios for the human health evaluations were developed on the basis of current and likely future land uses. Both carcinogenic and noncarcinogenic effects were evaluated. Foreseeable future land use at the Chemical Plant and surrounding area is likely to be recreational, which is the same as the current land use, which means potential exposure is only through access to spring water. However, on the basis of EPA guidance (EPA 1986) for groundwater classification, site groundwater could be classified as potentially usable from a water quality standpoint; that is, according to the EPA, a potential source of groundwater is one capable of yielding at least $150 \mathrm{gal} / \mathrm{d}$ to a well or spring, which is sufficient for the needs of a family. Also, a drinking water source must have a total dissolved solids concentration of less than $10,000 \mathrm{mg} / \mathrm{L}$ that can be supplied without treatment (MK-Ferguson and Jacobs Engineering Group 1990). Consequently, the assessment presented in the BRA (DOE and DA 1997a) also provided risk estimates for a hypothetical future resident scenario assuming access to groundwater contaminants.

The Army reservists scenario accounting for reservists that train at the adjacent Army training area was not evaluated because they do not have access to any active springs within the training area. In addition, the exposure assumptions (e.g., frequency and duration) for the recreational visitor scenario would account for the instances when these reservists would access the springs outside the training area while on personal time.

For the recreational visitor scenario, the assessment assumed conservatively that the recreational visitor would visit the area 20 times a year for 30 years for 4 hours each visit and each time ingest a cupful of spring water. For the hypothetical (adult) resident scenario, the assessment assumed ingestion of groundwater from a well for 350 days a year for 30 years, drinking 2 liters per day. In addition, because the toxic effect of nitrate (i.e., methemoglobinemia, or low blood oxygen levels) is primarily of concern for infants, a separate calculation for infants was performed to estimate potential toxicity to nitrate levels at the site. 
The risk estimates indicated that the recreational visitor (adult and infant) ingesting spring water from each of the springs with site contamination was not at increased risk for cancer and would not have adverse noncarcinogenic effects as a result of site contaminants. The assessment presented in the BRA indicated the hazard indices for a recreational visitor at the springs to range from less than 0.001 to 0.2 . The EPA has defined a hazard index of greater than 1 as indicating possible adverse noncarcinogenic health effects. The risk of developing cancer (from the combined effects of radiation and chemicals) was estimated to range from 4 in 1 billion to 2 in 1 million. For known or suspected carcinogens, the EPA has determined that acceptable exposure levels present an excess lifetime cancer risk to an individual of between 1 in 10,000 and 1 in 1 million. The estimates based on data collected since the BRA indicate lower hazard indices (0.001 to 0.015$)$ and risk levels (3 in 10 billion to 6 in 1 billion). Average uranium concentrations in 2002 at the Burgermeister Spring equate to a 3 in 1 billion risk, while average nitrate and uranium concentrations equate to a hazard index of less than 0.002 for both the adult and infant visitor.

For the hypothetical resident scenario, the assessment in the BRA indicated that several groundwater wells would exceed the hazard index of 1 due to nitrate (for both the adult and infant receptors) and nitroaromatic compounds. In addition, TCE concentrations in three wells result in risk greater than 1 in 10,000 (3 in 10,000 to 1 in $1,000)$; nitroaromatic compounds in one well result in risk greater than 1 in 10,000 ( 1 in 10,000); and uranium in six wells result in risk greater than 1 in 100,000 ( 1 in 100,000 to 7 in 100,000 ).

The estimates based on data collected since the BRA indicate similar results, with several wells still exceeding the hazard index of 1 primarily as a result of nitrate; risk levels are also generally the same, and the risks are at the same locations, with slightly lower maximums for TCE. Recent increases in nitroaromatic concentrations in a well by the Frog Pond area result in the risk being greater than 1 in 1,000 for that particular well. Maximum levels of risk from uranium are about the same.

The risk calculations indicate that the site contamination levels are acceptable for the recreational visitor but would not be acceptable for a resident scenario. In addition, groundwater concentrations for TCE, nitrate, uranium, and some of the nitroaromatic compounds exceed federal or state drinking water standards or MCLs. Therefore, restrictions on the residential use of groundwater will be necessary to protect human health until such time as when contaminant concentrations have decreased to levels equivalent to or below the MCLs.

The results of the ecological assessment indicate that contaminant concentrations in spring water and sediment pose little or no risk to ecological resources of the area and that remediation from an ecological perspective is not needed (DOE and DA 1997a).

Biotic surveys of macroinvertebrates, fish, and amphibians that inhabit the Burgermeister Spring drainage indicated no evidence of adverse effects. The spring was determined to contain generally good aquatic habitat, and the species present are typical of those found in similar habitats throughout the Midwest. Under low-flow conditions, as commonly occur in the summer, the stream drainage below the spring becomes intermittent, and portions of the habitat become dry. Surveys of amphibians found a community typical of similar habitats in the Midwest. Fish tissue analyses revealed relatively low levels of contaminant bioconcentration, all below levels of concern.

\section{REMEDIAL ACTION OBJECTIVES}

The remedial action objectives (RAOs) for the GWOU are as follows. (1) Provide protection 
of human health and the environment by attaining applicable or relevant and appropriate requirements [ARARs], including chemical-specific ARARs, and by reducing concentrations of COCs that have no ARARs to within the acceptable risk range. Risk-based concentrations [RBCs] equivalent to this range have been developed. (2) Ensure that land use remains consistent with groundwater and spring water use restrictions.

For the groundwater COCs, the following ARARs and RBCs have been identified: (1) $5 \mu \mathrm{g} / \mathrm{L}$ for TCE as a chemical-specific ARAR based on the federal MCL for drinking water; (2) $10 \mathrm{mg} / \mathrm{L}$ for nitrate as a chemical-specific ARAR based on the federal MCL for drinking water; (3) $20 \mathrm{pCi} / \mathrm{L}$ for uranium as a chemical-specific ARAR based on the recently promulgated federal MCL of $30 \mu \mathrm{g} / \mathrm{L}$ (the conversion to $20 \mathrm{pCi} / \mathrm{L}$ takes into account the isotopic ratios of uranium established for the Weldon Spring site); (4) $0.11 \mu \mathrm{g} / \mathrm{L}$ for 2,4-DNT, $1.0 \mu \mathrm{g} / \mathrm{L}$ for $1,3-\mathrm{DNB}$, and $17 \mu \mathrm{g} / \mathrm{L}$ for NB as chemical-specific ARARs based on State of Missouri water quality standards; and (5) 0.13 to $13 \mu \mathrm{g} / \mathrm{L}$ for $2,6-\mathrm{DNT}$ and 2.8 to $280 \mu \mathrm{g} / \mathrm{L}$ for 2,4,6-TNT as the RBC ranges based on equivalent concentrations of each of the contaminants to a risk range of 1 in 1 million to 1 in 10,000.

\section{SUMMARY OF REMEDIAL ALTERNATIVES}

The three alternatives described below were evaluated in selecting the preferred alternative. Conventional and innovative techniques for groundwater removal and treatment have been evaluated and demonstrated through extensive field testing conducted in 1998, 2001, and 2002 to be ineffective (DOE 2003b). The site hydrogeology presents significant implementability problems for pump-and-treat methods, and full-scale implementation cannot be effectively done. ICO was locally effective in treating TCE, but site hydrogeology makes full-scale application impractical (DOE 2003b). These active treatment alternatives were not retained for further evaluation because they are not implementable on a large scale, perform no better than the passive alternatives at reducing the contaminants, and do nothing to limit the need for ICs. However, ICO is retained as a contingency component of Alternative 3 for its potential to provide localized treatment of TCE.

\section{Alternative 1: No Further Action}

Estimated Capital Cost: $\$ 520,000$

Estimated Annual Operations and Maintenance (O\&M) Cost: $\$ 0$ Estimated Total Present Worth Cost: $\$ 520,000$

The "no further action" alternative is evaluated as a baseline for comparison with the other alternatives. No action would be taken under this alternative, nor would ICs be provided. However, abandonment of the existing network of monitoring wells would be performed and constitute a one-time cost that would be incurred.

\section{Alternative 2: Long-Term Monitoring with Institutional Controls}

Estimated Capital Cost: $\$ 450,000$

Estimated Annual O\&M Cost: $\$ 160,000$

Estimated Total Present Worth Cost: \$2,700,000

Estimated Construction Time Frame: 6 months

Estimated Time to Achieve RAOs: To be determined at 5-year reviews; costed for 100 years

Long-term groundwater monitoring would be conducted via an optimized network developed from the existing monitoring well network. Restrictions on groundwater use would be imposed to ensure that contaminated groundwater was not used for drinking purposes and not impacted by other activities such as pumping. Long-term groundwater monitoring would be performed to ensure that use restrictions remained appropriate 
over time. Use restrictions would be imposed through ICs. These ICs would remain in place as long as contaminant concentrations exceeded drinking water levels or MCLs. Nonattainment of drinking water standards would be addressed through technical impracticability waivers. As required under CERCLA, periodic reviews would be conducted no less than every five years to ensure that the remedy remains protective.

Use restrictions would apply to the aerial extent of the impacted groundwater, including an appropriate hydraulic buffer. DOE would monitor groundwater use by establishing a long-term surveillance program. For the land it controls (Chemical Plant property), DOE would place a notation on the federal acquisition land records. Restrictions within this notation would accrue to succeeding owners of the land. Similar restrictions would be placed on DA property, to be further supported with a Memorandum of Agreement (MOA) between DOE and DA. DOE would obtain formal agreements with the state for the surrounding areas owned by the MDC, MDNR, and the Missouri Department of Transportation (MoDOT). These ICs would be indefinite-term licenses, easements, or permits, as applicable.

\section{Alternative 3: Monitored Natural Attenuation with Institutional Controls}

Estimated Capital Cost: $\$ 530,000$

Estimated Annual O\&M Cost: $\$ 340,000$

Estimated Total Present Worth Cost: \$5,400,000

Estimated Construction Time Frame: 6 months

Estimated Time to Achieve RAOs: Approximately 100 years

Long-term groundwater monitoring would be conducted via an optimized network. Dilution and dispersion are the primary natural processes that act to reduce all contaminant concentrations in groundwater at the Chemical Plant area over time. Conditions do not appear to be favorable for biological processes degrading the TCE, nitroaromatic compounds, nitrates, or uranium. The source removal actions performed according to the Chemical Plant ROD (DOE 1993) ensure no further contaminant contribution to the groundwater. As a result, groundwater contaminant concentrations are expected to decrease with time. This alternative differs from Alternative 2 in that attenuation performance measures would be established, and the monitoring objectives would be designed to include verification that these measures would be met. This alternative also would include contingency measures to be undertaken in the event attenuation did not perform as expected.

On the basis of predictive calculations, it is anticipated that groundwater contaminant concentrations will attenuate to levels consistent with drinking water standards or MCLs in approximately 100 years. Monitoring would be performed to verify contaminant concentration decreases at wells and discharge points (at springs) over time. Trigger concentrations would be incorporated into the monitoring strategy so that pre-established contingency actions could be taken, as necessary. ICO would be retained as a contingency component for Alternative 3 for its potential to provide localized treatment of TCE.

As part of Alternative 3, ICs would also be required to provide protection of human health and the environment because of the approximately 100 years that it would take to approach MCLs or ARARs. ICs would be the same as those described for Alternative 2. Similarly, routine inspections for indications of groundwater use would be performed to ensure use restrictions were being adhered to.

\section{EVALUATION OF ALTERNATIVES}

The three alternatives were evaluated against the nine criteria stipulated in the National Oil and Hazardous Substances Pollution Contingency Plan (EPA 1990). The alternatives 
were also compared against each other in order to select the best remedy. Detailed analysis of these alternatives can be found in the Supporting Evaluation Report (DOE 2003b), the FS (DOE and DA 1998), and the Supplemental FS (DOE 1999).

\section{Overall Protection of Human Health and the Environment}

All of the alternatives except the "no further action" alternative would provide adequate protection of human health and the environment because the alternatives include components for either eliminating, reducing, or controlling exposure to the contaminated media. All alternatives except for "no further action" include ICs to restrict groundwater use during the remedial action period until protective levels or ARARs are met.

\section{Compliance with ARARs}

The principal ARARs for the impacted groundwater are the drinking water standards known as maximum contaminant levels (MCLs) under the Clean Water Act and Missouri Water Quality Standards. Alternatives 1 and 2 do not provide for these standards to be met and include no mechanism for establishing compliance with these standards. Under Alternative 2, nonattainment of ARARs would be addressed through technical impracticability waivers. Under Alternative 3, attainment of ARARs is a condition of adequate performance, and it is estimated that ARARs will be met in a time period of approximately 100 years. Alternative 3 relies on verification of natural attenuation processes to attain ARARs.

\section{Long-Term Effectiveness and Permanence}

Alternative 3 is considered to provide greater effectiveness and permanence than Alternative 2 over the long term because it establishes the objective of meeting health-based standards. Alternative 3 also employs more rigorous monitoring objectives than Alternative 2 and therefore allows for a greater understanding of fate and transport.

\section{Reduction of Toxicity, Mobility, or Volume of Contaminants through Treatment}

None of the three alternatives provides reduction of toxicity, mobility, or volume through treatment, as treatment is not a component in any of the three alternatives. Active treatment alternatives have been thoroughly investigated and discarded as ineffective.

\section{Short-Term Effectiveness}

Alternatives 2 and 3 are comparatively effective over the near term. Potential shortterm impacts associated with monitoring, implementation of ICs, and abandonment of wells are expected to be low, with less than one case of occupational injury and no occupational fatalities during construction or abandonment of wells.

\section{Implementability}

From a construction standpoint, Alternatives 2 and 3 are both implementable by using conventional methods for monitoring and construction of wells. The more rigorous monitoring objectives of Alternative 3 make it somewhat more difficult to develop than Alternative 2, but not substantially so. Establishing ICs will present some administrative challenges, but these are considered surmountable, given that current land use and groundwater use are not impacted by needed restrictions and that impacted lands are owned by the federal and state governments. In any event, the challenges are the same for each alternative.

\section{Cost}

Alternative 3 has the highest capital, annual, and total present net-worth costs of the three alternatives. 


\section{State Acceptance}

The MDNR has indicated support for an MNA remedy provided that adequate performance measures and contingencies are incorporated.

\section{Community Acceptance}

Community acceptance of the preferred alternative will be evaluated after the public comment period ends and will be addressed in the responsiveness summary that will be provided with the upcoming ROD for the GWOU.

\section{PREFERRED ALTERNATIVE}

DOE has determined that Alternative 3 provides the best balance of trade-offs among the alternatives when evaluated against the balancing criteria. Therefore, the preferred alternative for the remaining groundwater contamination is MNA, with ICs being used to restrict groundwater use during the restoration period.

Calculations performed to estimate the amount of time (in years) that will be required for dilution and dispersion to reduce contaminant concentrations to levels equivalent to chemicalspecific ARARs indicate time frames of approximately 100 years (DOE 2003b).

Groundwater and spring water use restrictions will be imposed on the area of the former Chemical Plant and ranging to the Burgermeister Spring in the north and including the Southeast Drainage to the south. Figure 4 depicts the area where ICs will be implemented. A surveillance program will be established to ensure that groundwater use restrictions are maintained. Routine inspections will be performed to look for indications of groundwater use or withdrawal and ensure that uses inconsistent with the restrictions are not taking place. See the description of Alternative 2, pages 10 and 11, for more information on the types of ICs that could be employed. The IC implementation and surveillance plan is a component of the Long-Term Surveillance and Maintenance Plan (LTS\&MP) (DOE 2003a).

MNA is considered a good approach because the expectation is that the contaminant plumes will continue to disperse and become more diluted with natural recharge from rain water. Since the various sources of the contaminants have been removed as a result of the Chemical Plant remedial action, groundwater quality should continue to improve. The overall area of contamination should not become larger than it currently is, as depicted by the institutional control boundary shown in Figure 4. Most contaminant migration is to the north toward Burgermeister Spring along preferential flow paths, and contamination is not expected to migrate any deeper than it already has. With diminishing concentrations at the springs, the potential risk to the recreational visitor should remain low and continue to diminish along with contaminant concentrations.

For purposes of verifying the conditions described above, the objectives of the groundwater monitoring plan for the MNA are to (1) monitor the unweathered or deeper portion of the shallow aquifer to verify that contamination is generally limited to the shallow, weathered zones; (2) measure concentration trends to verify that natural attenuation is occurring as expected; (3) monitor perimeter locations to ensure that the contaminant plumes are not expanding or migrating unexpectedly; (4) measure contaminant concentration trends at the springs and verify that conditions remain protective on the basis of current recreational use; (5) perform upgradient monitoring; and (6) measure water levels to demonstrate hydrologic stability.

Specific trigger concentrations will be established for each contaminant of concern and for each of the six MNA monitoring objectives 


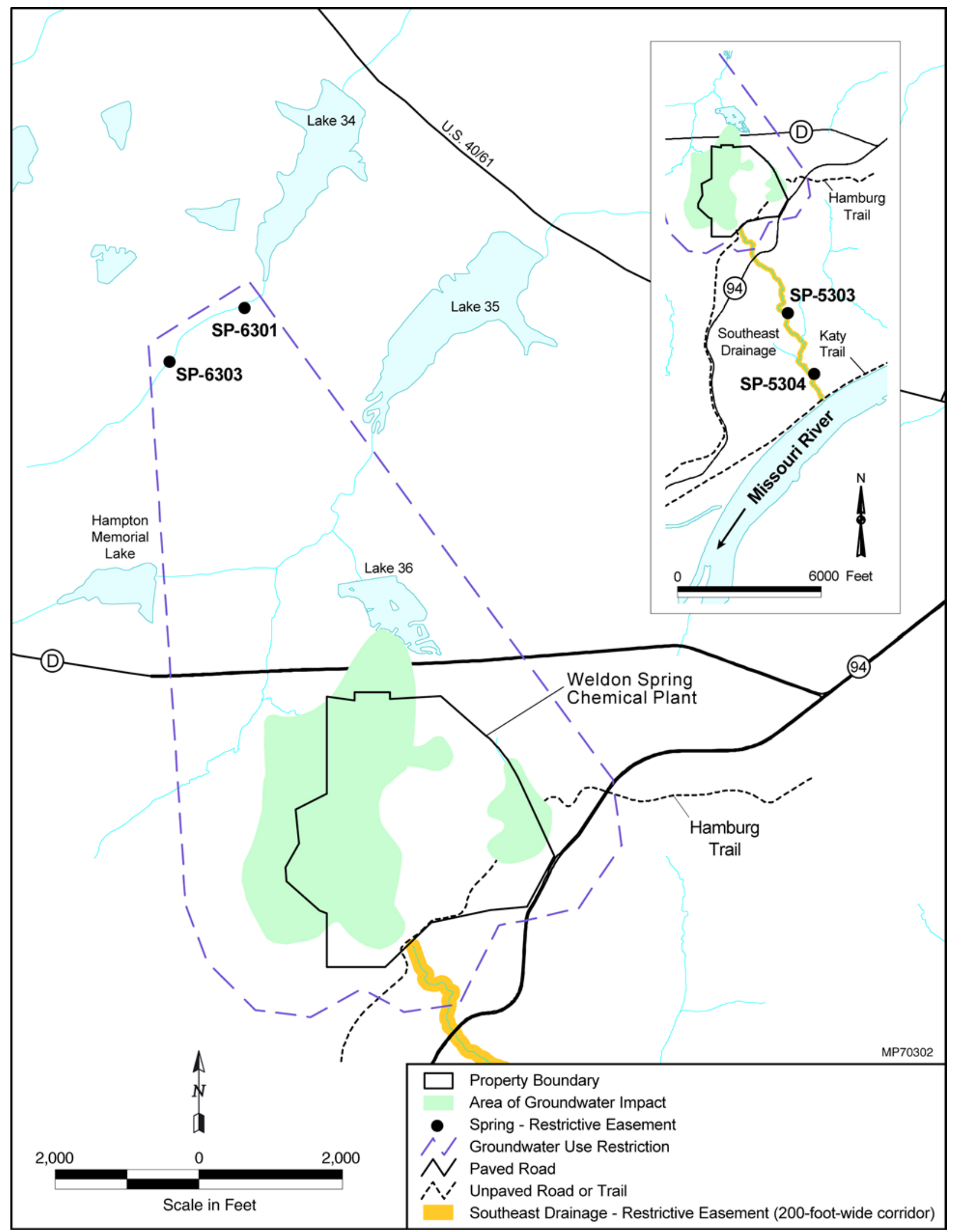

Figure 4 Institutional Controls Location Map for the Chemical Plant Area 
described above as part of the remedial design process. Trigger concentrations will be established within the contaminant the plumes, downgradient of the plumes in both the horizontal and vertical directions, and at potential exposure points or locations (i.e., springs). Within the plumes, the trigger concentrations will be representative of historical highs. Downgradient of the plumes, the trigger concentrations will be selected on the basis of dispersion and dilution expectations within the IC area. At the springs, the trigger concentrations will consider health-based values and historical trends.

Exceedance of these trigger values will be considered an indicator that natural attenuation is not performing as anticipated. Specific contingencies will be established to address these situations if they arise. Contingencies include an increase in sampling frequency and density, reevaluation of predicted MNA time frames, and localized treatment of TCE depending on the nature of the situation.

The remedial action plan containing the details of this monitoring and contingency program will be finalized in the RD/RA work plan and made a component of the LTS\&MP. See the supporting evaluation report (DOE 2003b) for representative details on the anticipated design of the monitoring and contingency program.

In accordance with the requirements of CERCLA, periodic reviews will be conducted no less often than every five years for as long as groundwater contaminant concentrations remain at levels that do not allow for unlimited use and unrestricted exposure. Annual reviews and monitoring will be performed in accordance with the LTS \& MP.

\section{SUMMARY}

DOE selected the preferred alternative because it provides overall protection of human health and the environment, it meets ARARs within a time frame that is considered reasonable when compared against available options, and it is cost effective. Active treatment alternatives have been investigated and determined to be ineffective. The EPA and the MDNR have indicated a favorable response to the preferred alternative described in this report, although details regarding the design of the monitoring program require significant additional discussions. The public is encouraged to review and provide comment on this proposal. Information regarding an upcoming public meeting and where to send comments can be found on page 2 of this plan.

\section{GLOSSARY OF TERMS}

Anisotropic - Anisotropic conditions in groundwater mean that the characteristics of the groundwater flow across the site can be significantly different in one location than another.

\section{Applicable or Relevant and Appropriate Requirements (ARARs) - "Applicable"} requirements are those cleanup standards of control, and other substantive environmental protection requirements, criteria, or limitations promulgated under federal or state law, that specifically address a hazardous substance, pollutant, contaminant, remedial action, location, or other circumstance at a Comprehensive Environmental Response, Compensation, and Liability Act (CERCLA) site. "Relevant and appropriate" requirements are those cleanup standards that, while not "applicable" at a CERCLA site, address problems or situations sufficiently similar to those encountered at the CERCLA site that their use is well-suited to the particular site. ARARs can be action-specific, location-specific, or chemical-specific.

Aquifer - A geologic formation that is water bearing. It can be a layer of soil, sand, gravel, or rock that will yield economically significant quantities of water to a well or spring. 
Confined Aquifer - An aquifer that is completely filled with water under pressure and that is overlain by material that restricts the movement of water.

Core Loss - A zone within a rock core where no rock is present and likely represents the location of a void or enlarged fracture that can be open or clay-filled.

Dilution - The reduction of a solute concentration through the introduction of a volume of uncontaminated groundwater.

Dispersion - The spreading and mixing of a solute in flowing groundwater with uncontaminated groundwater, resulting in reduced concentration. Dispersion is caused by both differences in the water velocity at the pore level and differences in the rate at which water travels through the aquifer materials in the flow path.

Fracture - A crack or break in bedrock.

Groundwater Divide - The boundary between two adjacent groundwater basins, which is represented by a high point in the water table. The groundwater divide that runs west-east through the southern portion of the site means that groundwater south of the divide flows toward the Missouri River, while groundwater north of the divide flows toward the Mississippi River.

Heterogeneous - Nonuniform in structure or composition throughout. This is similar in concept to anisotropic, where there are significant changes in conditions from one location compared to another nearby location.

Hydraulic Conductivity - The rate at which water can move through a permeable medium (i.e., soil or rock).

Institutional controls - Controls such as deed restriction and permitting requirements that prohibit or limit activities that may result in exposure to contamination. Effective institutional controls must remain in effect for the duration of the hazard, survive a change in property ownership, and be enforceable. Institutional controls also include those that preserve knowledge and facilitate public education regarding hazards at a site in order to enhance protectiveness into the future.

Karst - The type of geologic terrain underlain by carbonate rocks where significant solution of the rock has occurred due to flowing groundwater.

Losing Stream - A surface stream or segment of a stream that is losing water by seepage into the ground or subsurface.

Maximum Contaminant Level (MCL) - The maximum allowable level of a contaminant that federal or state regulations allow in a public water system. If the MCL is exceeded, the water system must treat the water so that if meets the MCL.

Paleochannel - A drainage channel that existed on the ground surface in the past that, due to later deposition of materials, is now beneath the ground surface. Paleochannels typically have materials of higher permeability due to weathering of the bedrock and result in locations where groundwater movement is faster than it is through surrounding unweathered rock.

Solution Feature - A feature in carbonate bedrock formed by the weathering and/or erosion by groundwater. Solution features include vugs, cavities, voids, enlarged fractures, or sinkholes.

Spring - A location where a natural discharge of groundwater from rock or soil flows onto the land surface or into a body of surface water.

Transmissivity - The rate at which groundwater is transmitted though a unit width of an aquifer under a unit hydraulic gradient. It is a function of the properties of the liquid (water), porous media 
(aquifer), and the thickness of the aquifer and is used to judge the aquifer's production potential.

Unconfined Aquifer - An aquifer in which there are no confining beds between the zone of saturation and the surface. An aquifer where the water table is exposed to the atmosphere through openings in the overlying materials.

Unweathered Rock - Rock that has not been changed by physical disintegration and/or chemical decomposition.
Vug - A cavity, often with a mineral lining of different composition from that of the surrounding rock.

Weathered Rock - Rock that has been changed or broken down and decomposed by the action of external elements such as wind, rain, temperature changes, plants, and bacteria. 


\section{REFERENCES}

Basko, R., 2003, e-mail from Basko (Missouri Department of Health and Senior Services, St. Louis, MO) to R. Cato (Weldon Spring Site Remedial Action Project, St. Charles, MO), May 22.

DOE (U.S. Department of Energy), 1992, Remedial Investigation for the Chemical Plant Area of the Weldon Spring Site, DOE/EIS-0185D (DOE/OR/21548-074, Vol. I), prepared by MKFerguson Company and Jacobs Engineering Group, Inc., Weldon Spring, MO, for U.S. Department of Energy, Oak Ridge Field Office, Weldon Spring Site Remedial Action Project, Weldon Spring, MO, Nov.

DOE, 1993, Record of Decision for Remedial Action at the Chemical Plant Area of the Weldon Spring Site, DOE/OR/21548-376, prepared by U.S. Department of Energy, Oak Ridge Field Office, Weldon Spring Site Remedial Action Project, Weldon Spring, MO, Sept.

DOE, 1999, Supplemental Feasibility Study for Remedial Action for the Groundwater Operable Unit at the Chemical Plant Area of the Weldon Spring Site, Weldon Spring, Missouri, DOE/OR/21548-783, prepared by Argonne National Laboratory, Argonne, IL, for U.S. Department of Energy, Weldon Spring Site Remedial Action Project, Weldon Spring, MO, June.

DOE, 2000, Interim Record of Decision for Remedial Action for the Groundwater Operable Unit at the Chemical Plant Area of the Weldon Spring Site, DOE/OR/21548-798, prepared by U.S. Department of Energy, Oak Ridge Operations Office, Oak Ridge, TN, Sept.

DOE, 2003a, Draft Long-Term Surveillance and Maintenance Plan for the Weldon Spring, Missouri, Site, GJO-2002-342-TAC, prepared by
U.S. Department of Energy, Grand Junction Office, Grand Junction, CO, May.

DOE, 2003b, Supporting Evaluation for the Proposed Plan for Final Remedial Action at the Groundwater Operable Unit at the Chemical Plant Area of the Weldon Spring Site, Weldon Spring, Missouri, DOE/GJ/79491-934, prepared by Argonne National Laboratory, Argonne, IL, for U.S. Department of Energy, Weldon Spring Site Remedial Action Project, Weldon Spring, MO, June.

DOE and DA (U.S. Department of Energy and U.S. Department of the Army), 1997a, Baseline Risk Assessment for the Groundwater Operable Units at the Chemical Plant Area and the Ordnance Works Area, Weldon Spring, Missouri, DOE/OR/21548-568, prepared by Argonne National Laboratory, Argonne, IL, for U.S. Department of Energy, Weldon Spring Site Remedial Action Project, Weldon Spring, MO, and U.S. Department of the Army, Corps of Engineers, Kansas City District, Kansas City, MO, July.

DOE and DA, 1997b, Remedial Investigation for the Groundwater Operable Units at the Chemical Plant Area and the Ordnance Works Area, Weldon Spring Site, Weldon Spring, Missouri, DOE/OR/21548-571, prepared by MK-Ferguson Company and Jacobs Engineering Group, Inc., Weldon Spring, MO, and Argonne National Laboratory, Argonne, IL, for U.S. Department of Energy, Weldon Spring Site Remedial Action Project, Weldon Spring, MO, and U.S. Department of the Army, Corps of Engineers, Kansas City District, Kansas City, MO, July. (see p. 5-10 for TCE and p. D-9 for 2,6-DNT)

DOE and DA, 1998, Feasibility Study for Remedial Action for the Groundwater Operable Units at the Chemical Plant Area and the Ordnance Works Area, Weldon Spring, Missouri, DOE/OR/21548-569, prepared by Argonne National Laboratory, Argonne, IL, for U.S. Department Energy, Weldon Spring Site 
Remedial Action Project, Weldon Spring, MO, and U.S. Department of the Army, Corps of Engineers, Kansas City District, Kansas City, MO, Dec.

EPA (U.S. Environmental Protection Agency), 1986, Guidelines for Ground-Water Classification under the EPA Ground-Water Protection Strategy, Final Draft, Washington, DC.

EPA, 1990, "National Oil and Hazardous Substances Pollution Contingency Plan; Final Rule (40 CFR Part 300)," Federal Register 55(46):8666-8865, March 8.

MK-Ferguson Company and Jacobs Engineering Group, 1990, Groundwater Classification for the Weldon Spring Site Remedial Action Project, Weldon Spring, Missouri, DOE/OR/21548-116, prepared for U.S. Department of Energy, Oak Ridge Field Office, Weldon Spring Site Remedial Action Project, Weldon Spring, MO, April.
MK-Ferguson Company and Jacobs Engineering Group, 1998, Completion Report for the Pilot Pumping Test for the Groundwater Operable Unit at the Weldon Spring Site, DOE/OR/21548-757, prepared for U.S. Department of Energy, Oak Ridge Operations Office, Weldon Spring Site Remedial Action Project, St. Charles, MO, Oct.

Vogel, J., 2003, e-mail from Vogel (Missouri Department of Conservation, St. Charles, MO) to P. Thompson (U.S. Department of Energy, Weldon Spring Remedial Action Project, St. Charles, MO), April 3. 
APPENDIX A:

CONTAMINANT CONTOURS 
A-2 


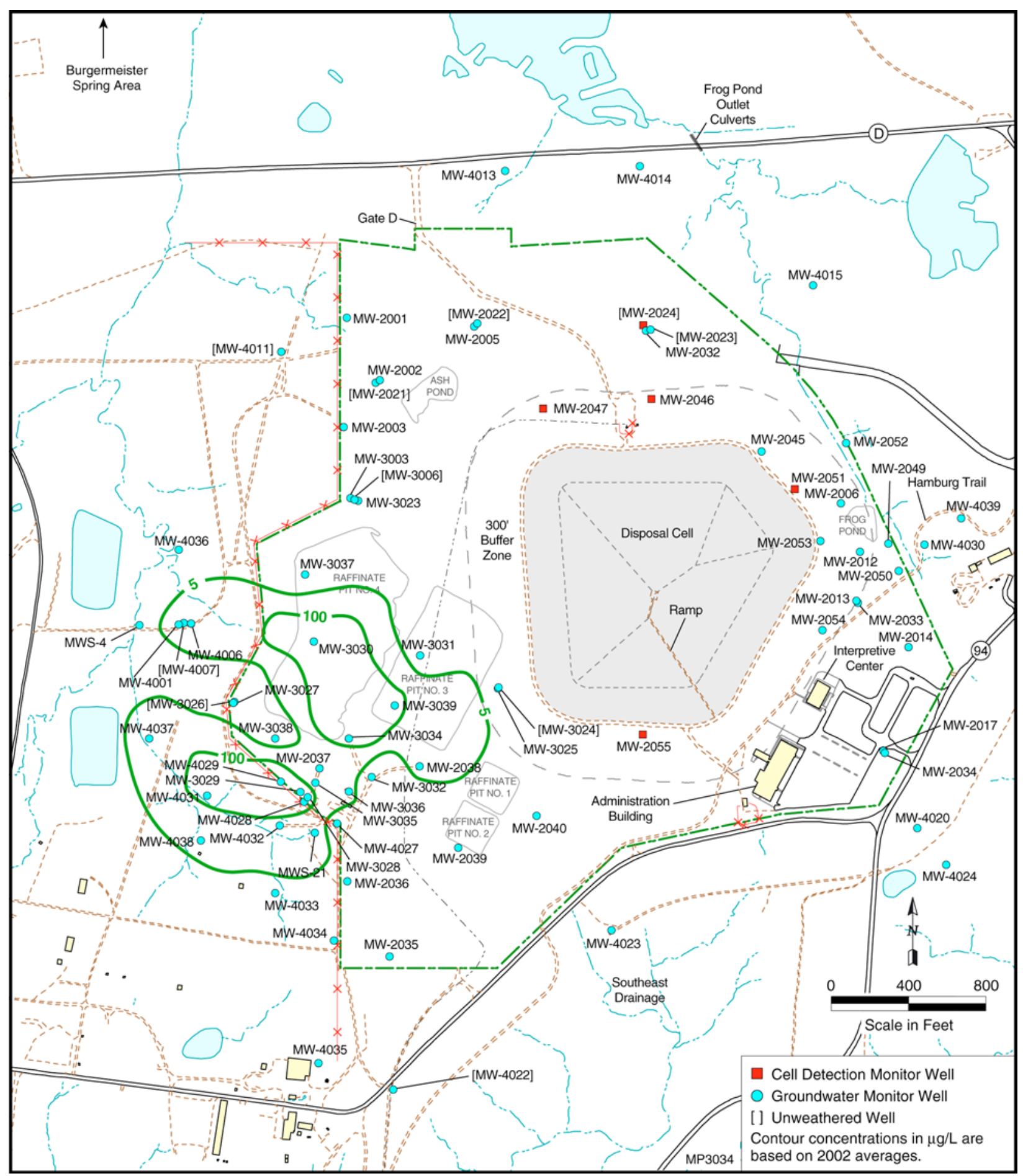

Figure A.1 TCE Contamination Contour Based on Average Concentrations for 2002 at the Chemical Plant Area 


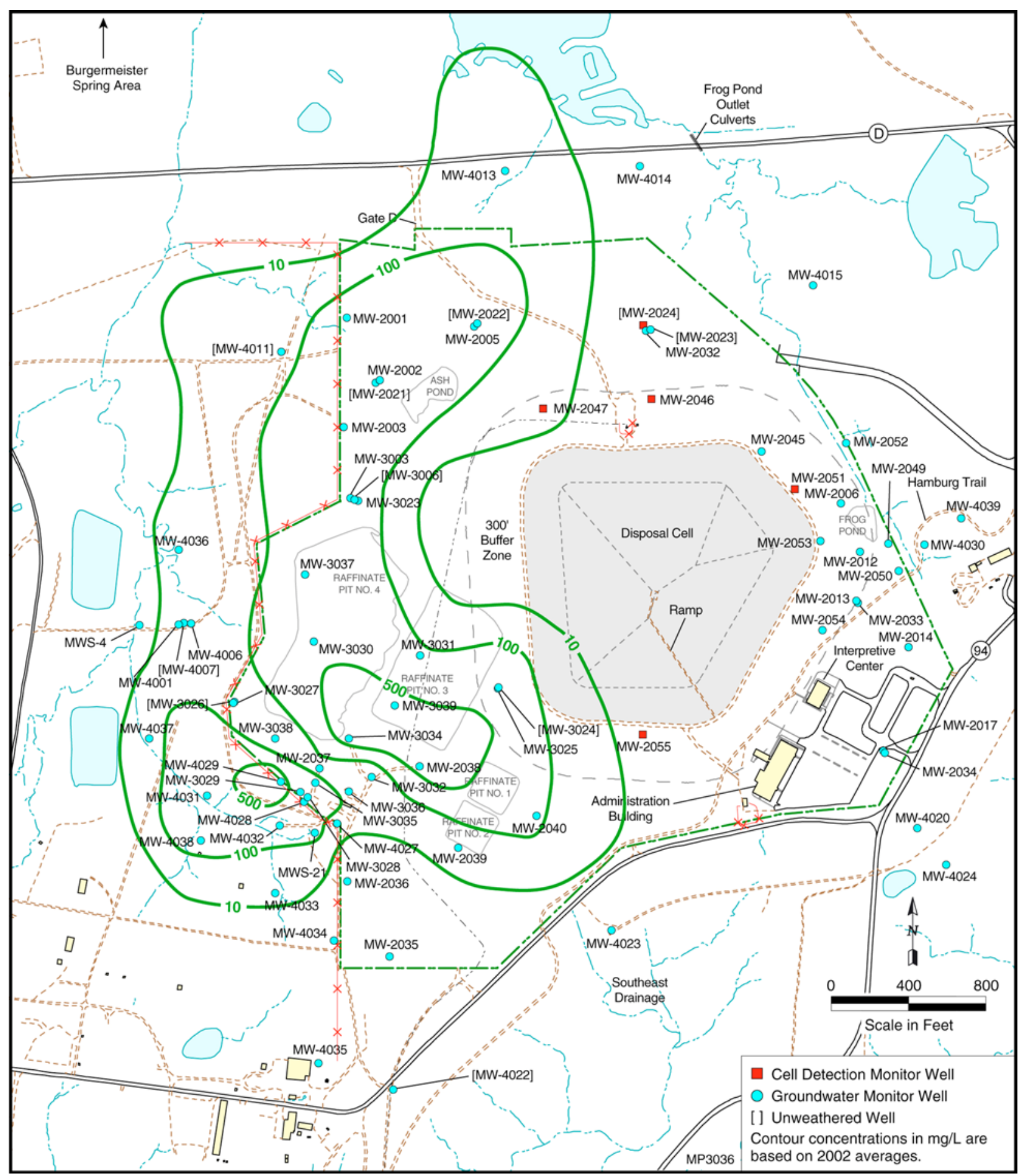

Figure A.2 Nitrate Contamination Contour Based on Average Concentrations for 2002 at the Chemical Plant Area 


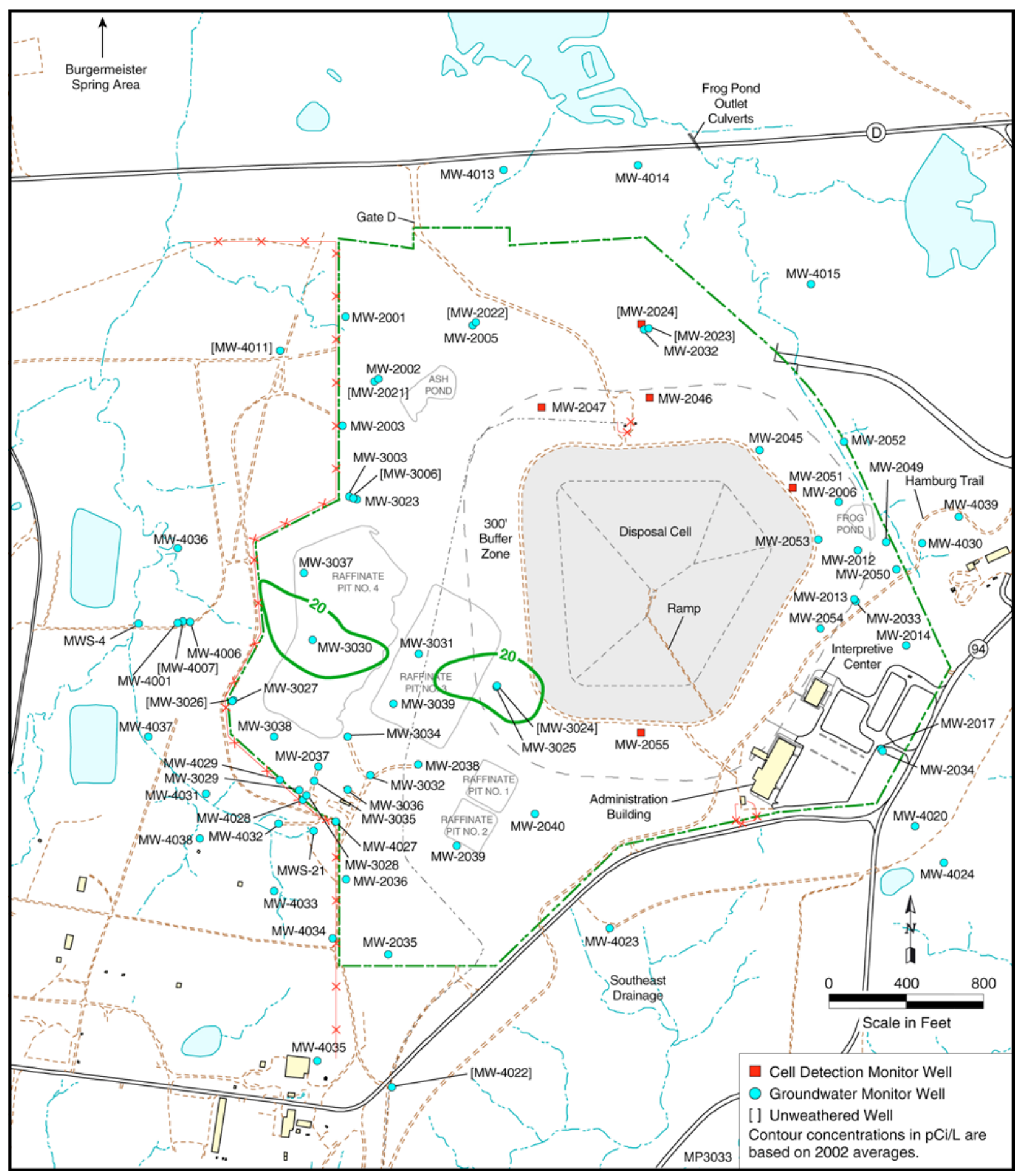

Figure A.3 Uranium Contamination Contour Based on Average Concentrations for 2002 at the Chemical Plant Area 


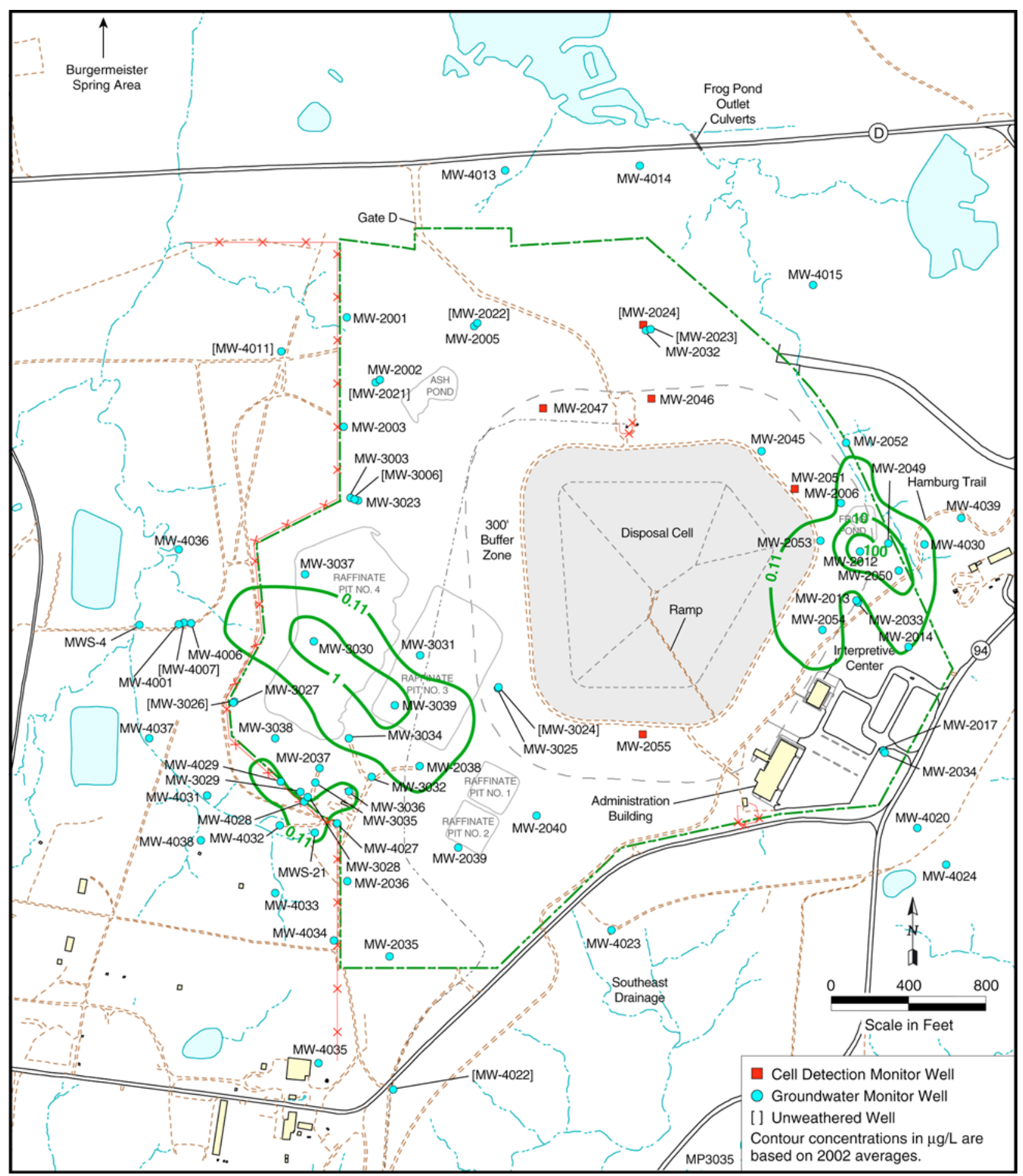

Figure A.4 2,4-DNT Contamination Contour Based on Average Concentrations for 2002 at the Chemical Plant Area 


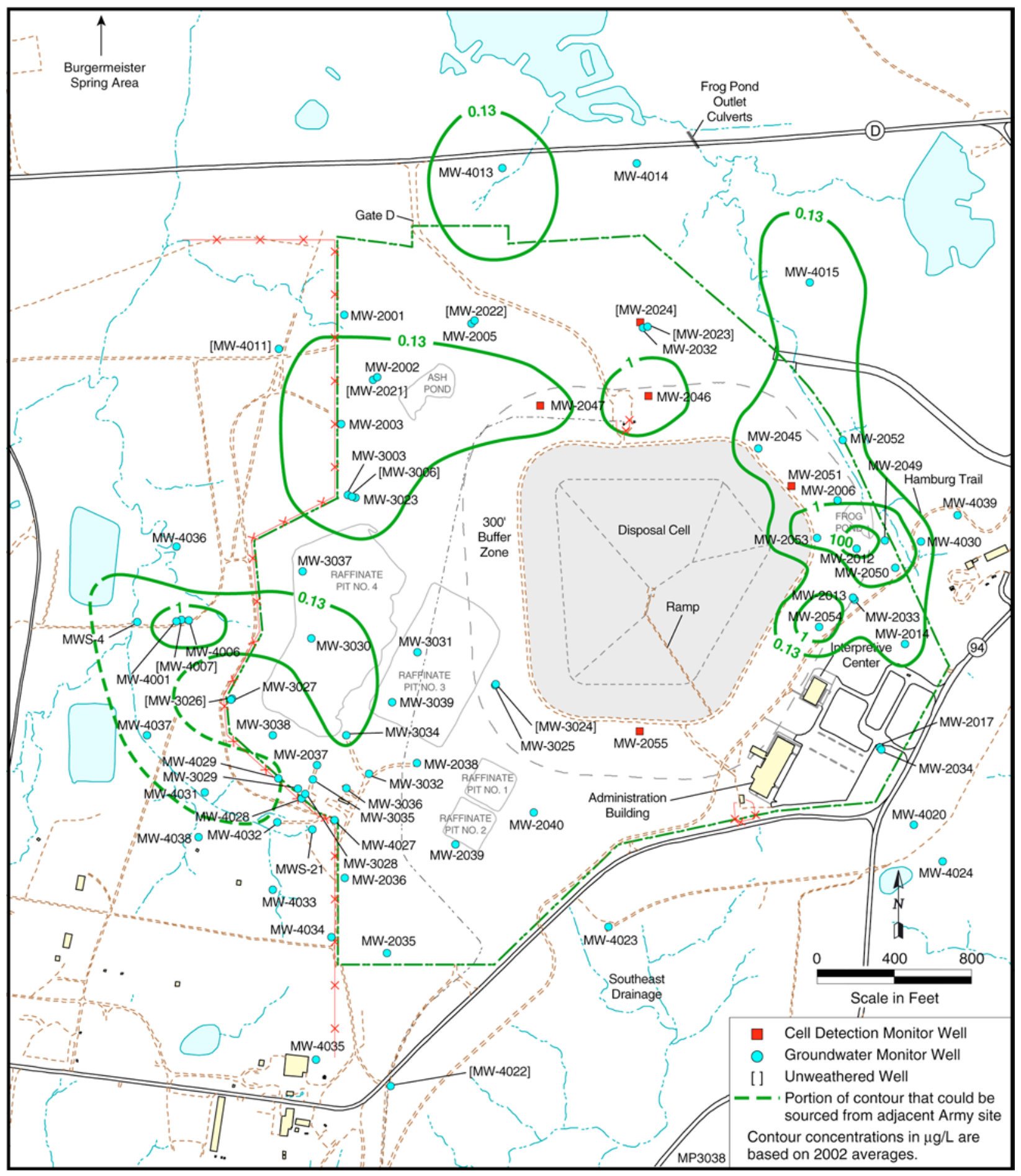

Figure A.5 2,6-DNT Contamination Contour Based on Average Concentrations for 2002 at the Chemical Plant Area 


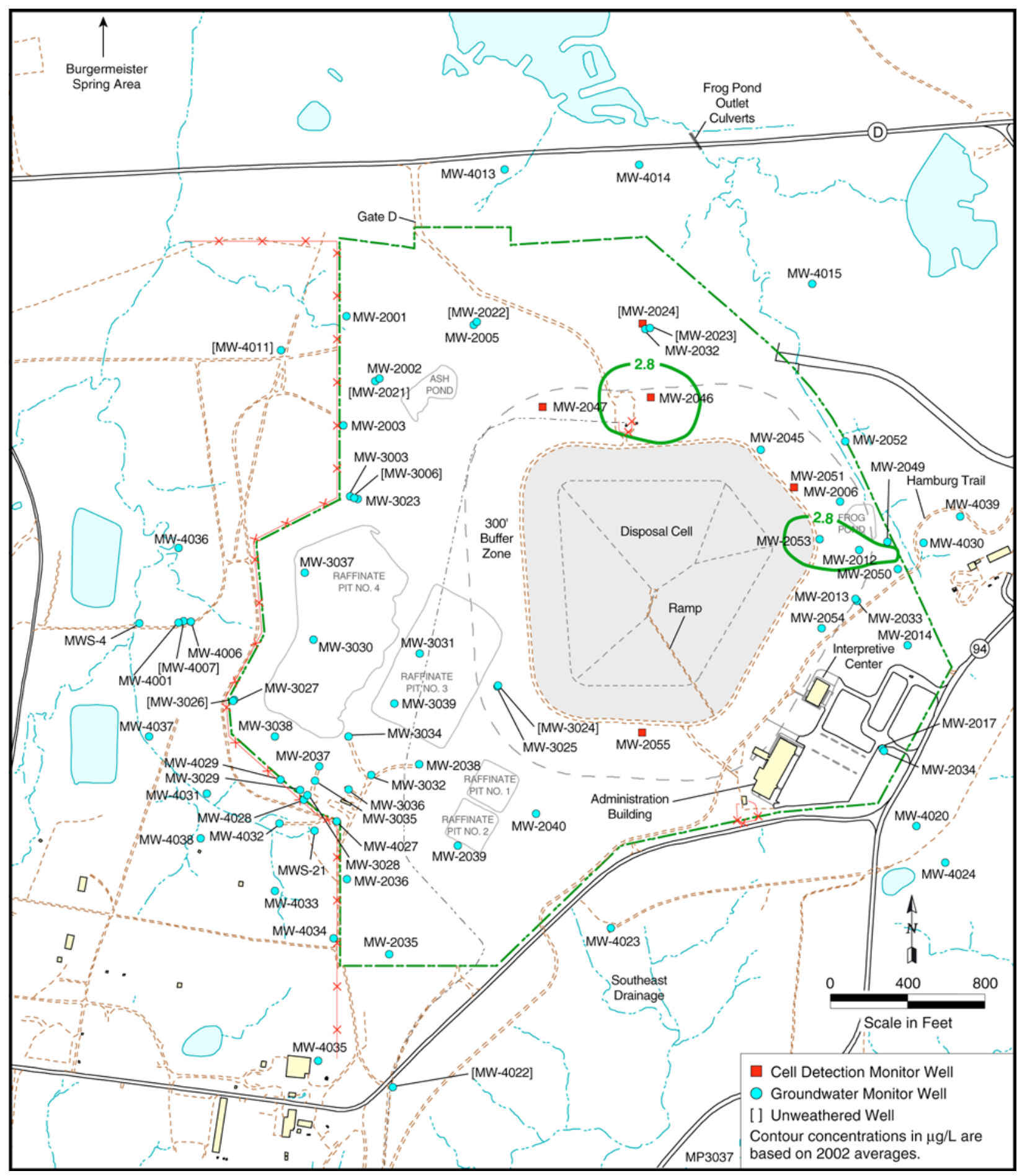

Figure A.6 2,4,6-TNT Contamination Contour Based on Average Concentrations for 2002 at the Chemical Plant Area 